Jurnal Qua Teknika, Vol. 6 No. 1 Maret 2016

p ISSN: 2088 2424; e ISSN: 2527 3892

UNISBA Blitar, Http://qua.unisbablitar.ejournal.web.id

Bambang Satria Purwita. 2016. Kontak Pemutus Daya Pada Tegangan Pemulihan Dalam Melindungi

Jaringan Transmisi Tegangan Tinggi. Jurnal Qua Teknika, (2016), 6(1):16 31.

\title{
KONTAK PEMUTUS DAYA PADA TEGANGAN PEMULIHAN DALAM MELINDUNGI JARINGAN TRANSMISI TEGANGAN TINGGI
}

\author{
Bambang Satria Purwita \\ Institut Teknologi Nasional \\ Jl. Bendungan Sigura-Gura No. 2, Lowokwaru, Malang
}

Pada umumnya kita telah mengetahui seringnya gangguan terhadap jaringan transmisi adalah gangguan alam, seperti gangguan kilat terhadap jaringan transmisi disebabkan jaringan transmisi yang melalu udara, panjang, tinggi dan tersebar diberbagai daerah terbuka serta beroperasi dalam segala macam kondisi. Diantara pertimbangan-pertimbangan yang diambil dalam perancangan pemerisaian saluran transmisi adalah letak kawat tanah terhadap kawat fasa. Karena kawat tanah saja, sehingga persentase kecil saja pada kawat fasa. Dan sampai sekarang belum ada sarjana-sarjana yang menunjukan kegunaan kilat bagi kehidupan, belum mendapat jalan untuk mencegah atau memanfaatkan energi yang ditimbulkan oleh petir tersebut. Walaupun demikian ilmu pengetahuan menusia tetap berkembang dengan kemajuan teknologi. Dengan salah satu alat pengaman, kawat udara (Overhead Ground Wire) untuk melindungi kawat- kawat fasa dari jaringan transmisi.

\section{PENDAHULUAN}

Pada akhir abad ke-19 sistem tenaga listrik dibumikan. Hal ini dapat dimengerti karena pada waktu itu sitem-sistem tenaga listrik masih kecil, jadi bila ada gangguan kawat bumi arus gangguan masih kecil ( $\pm 5 \mathrm{~A})$. Pada umumnya bila arus gangguan itu sebesar 5A atau lebih kecil busur listrik yang timbul pada kontak-kontak antara kawat yang terganggu dan bumi masih dapat padam sendiri (Self Extinguishng). Tetapi sistem-sistem tenaga itu makin lama makin besar baik panjangnya maupuan tenaganya. Dengan demikian arus yang timbul bila terjadi lagi gejala-gejala "Arching Grounds" semakin menonjol. Gejalan ini sangat berbahaya karena akan menimbulkan tegangan lebih transient yang dapat merusak alat-alat.Oleh karena itu mulai abad-20, pada saat sistem-sistem tenaga mulai besar sistim-sistem itu tidak lagi dibiarkan terisolasi (Isolated) yang dinamakan system delta tetapi titik netral system itu dibumikan mulalui tahanan atau reaktansi. Pembumian itu umunya dilakukan dengan menghubungkan netral transformator ke bumi.Pada umumnya di Indonesia, pemakaian jaringan transmisi tegangan tinggi. yang terletak pada daerah khatulistiwa, jumlah hari guruh sangat tinggi. Di pulau Jawa jumlah hari buruh berkisar antara 90 - 200an. Sumber ganguan yang paling besar disalurakan transmisi adalah gangguan sambaran kilat dan kemudian menyusul kaarena gangguan alam lainnya.

Tujuan dari Penelitian ini adalah untuk memperoleh pemahaman yang jelas mengenai perhitungan pelindungan pada jaringan transmisi tegangan tinggi. Dan pada gilirannya penulis ini juga untuk memenuhi syarat kelulusan/pencapaian gelar sarjana.

Penulisan hanya ingin membicarakan mengenai pengaman pendukung jaringan transmisi tegangan tinggi seperti pembumian untuk penyaluran daya yang berlebih akibat yang ditimbulkan sambaranpetir mengenai kawat tanah udara (Overhead Ground Wire) sebagai 
pelindung(Shielding) jaringan transmisi tegangan tinggi.Penggunaan kawat tanah ditujukan untuk pengaman mengenai kawat fasa. Disini kawat tanah berfungsi sebagai pelindung (Shielding), energi sambaran kilat akan dialirkan kedalam bumi melalui tiang atau menara yang dibumikan setelah lebih dahulu ditangkap oleh kawat tanah tersebut.Kita telah mengetahui bahwa kilat merupakan aspek gangguan yang berbahaya terhadap seluran transmisi yang menggagalkan keandalan dan keamanan sistem tenaga dan tak mungkin dihindarkan, sedangkan alat-alat pengaman seperti : Arester, Fuse Gap dan Rodgap terbatas kemampuannya maka untuk mengurangi akibat yang di timbulkan sambaran petir digunkanla kawat tanah udara (Overhead Ground Wire) sehigga koordinasi isolasi akan lebih ekonomis.

\section{METODE}

Teori gelombang berjalan pada kawat transmisi telah disusun secara intensif sejak tahun 1910, terlebih-lebih dalam 1930-an. Persoalan gelombang berjalan ini sangat sukar, sehingga harus diadakan banyak penyederhanaan supaya dapat dipergunakan untuk keperluan teknik pada saat ini gelombang berjalan telah diselidiki pada :
a. Kawat Tunggal
b. Kawat Majemuk
c. Kecepatan mejemuk dari gelombang berjalan
Bagian terbesar dari suatu mengenai gangguan pada system ialah teori gelombang berjalan, yaitu mengenai sumber gelombang, karakteristik serta keadaan pada titik peralihan dari transmisi.

\section{TEORI}

\subsection{Sumber-Sumber Gelombang Berjalan}

Sampai saat ini sebab-sebab dari gelombang berjalan yang di ketahui ialah :

a. Sambaran kilat secara langsung pada kawat fasa

b. Sambaran kilat tidak langsung pada kawat fasa (Induksi)

c. Operasi hubung (Switching Operation)

d. Gangguan-gangguan pada sistem oleh berbagai kesalahan

e. Tegangan stady state

Semua macam sebab-sebab ini menimbulkan seya (surge) pada kawat fasa disebebkan oleh kelebihan energi secara tiba-tiba pada kawat. Energi ini merambat pada kawat fasa, sama halnya seperti kita melemparkan baru pada air yang tenang pada sebuah kolam. Energi yang merambat ini terdiri dari arus dan tegangan. Kecepatan merambat gelombang berjalan tergantung dari konstanta-konstanta kawat fasa. Pada kawat hantaran udara, kecepatan merambat ini kira-kira 1000ft/ $\mu$ sec, jadi sama dengan kesepatan cahaya. Pada kebel tanah kira-kira $500 \mathrm{ft} / \mu$ sec.Dengan sendirinya segala macem diskontinuitas pada transmisi tidak mempunyai efek pada gelombang, sebelum gelombang mencapainya. Tetapi bila gelombang mencapai titik peralihan, terjadi perubahan gelombang sehingga terdapat sedikit perbedaan dengan gelombang semula.

Kecepatan Merambat

Apabila suatu gelombang energi listrik merambat sepanjang kawat fasa dengan konstanta $\mathrm{L}$ dan $\mathrm{C}$, maka gelombang tegangan dengan arus merambat dengan kecepatan yang sama. Kedua besaran ini dihubungkan oleh suatu factor proposional yaitu karakteristik fasa itu. 
Jurnal Qua Teknika, Vol. 6 No. 1 Maret 2016

p ISSN: 2088 2424; e ISSN: 2527 3892

UNISBA Blitar, Http://qua.unisbablitar.ejournal.web.id

Bambang Satria Purwita. 2016. Kontak Pemutus Daya Pada Tegangan Pemulihan Dalam Melindungi Jaringan Transmisi Tegangan Tinggi. Jurnal Qua Teknika, (2016), 6(1):16 31.

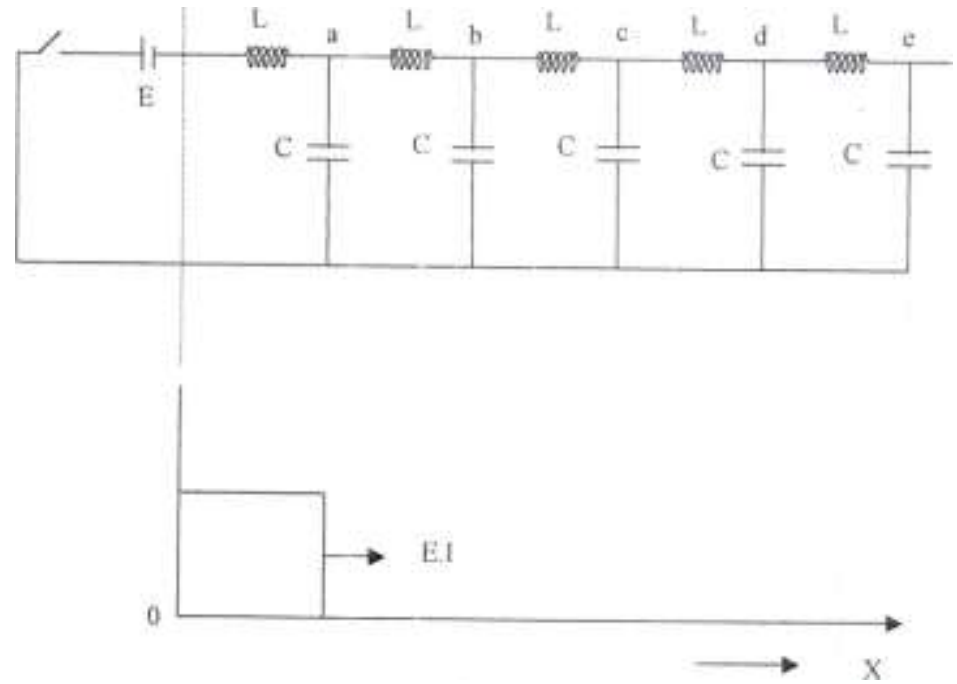

Gambar 3.1 Kawat Transmisi dengan batere

Bila gelombang tegangan E sampai pada titik a, maka arus yang bersamaan dari tegangan itu akan mengisi kapasitor C pada tegangan E.Muatan yang dibutuhkan untuk menaikan tegangan pada satu satuan panjang dama dengan CE.Bila kecepatan merambat gelombang itu $\mathrm{v} \mathrm{cm} /$ detik, maka jumlah muatan yang dibutuhkan untuk mengisi kawat sepanjang $\mathrm{v} \mathrm{cm}$ tiap detik sama dengan $\mathrm{C} \mathrm{E}$ v. Muatan ini diberikan oleh arus uniform yang mengalir pada kawat, dan memberikan muatan $\mathrm{C} \mathrm{E}$ v dalam satu detik dibutuhkan arus sebesar :

$\mathrm{I}=\mathrm{C} \mathrm{E} \mathrm{v}$

Bila gelombang itu merambat sejauh $\mathrm{x} \mathrm{cm}$, maka energi elektrostatik pada bagian ini ( $\mathrm{x}$ $\mathrm{cm})$ ialah:

$\mathrm{Wc}=1 / 2 \mathrm{C} \times \mathrm{E}^{2}$

Bila L sama dengan induktansi kawat per $\mathrm{cm}$, maka dalam waktu yang sama, energi elektromagnetik pada kawat sepanjang $\mathrm{x}$ itu :

$\mathrm{W}_{\mathrm{L}}=1 / 2 \mathrm{~L} \mathrm{x} \mathrm{I}^{2}$

Dimana :

$\mathrm{Wc}=$ Energi elektrostatik

$\mathrm{W}_{\mathrm{L}}=$ Energi elektromagnetik

$\mathrm{C}=$ Kapasitor

$\mathrm{L}=$ Induktansi

$\mathrm{E}=$ Tegangan batere

I = Arus yang mengantar pada kawat fasa

Satu-satunya sumber energi disini batere. Bila dibutuhkan waktu $t$ entuk merambat sepanjang $\mathrm{x} \mathrm{cm}$,

$\mathrm{v}=\mathrm{x} / \mathrm{t}$

Energi yang diberikan oleh batere

$\mathrm{W}_{\mathrm{e}}=\mathrm{E}$ I t

$\mathrm{W}_{\mathrm{e}}=\mathrm{Wc}+\mathrm{W}_{\mathrm{L}}$

Jadi : $\quad \mathrm{EIt}=1 / 2 \mathrm{C} \times \mathrm{E}^{2}+1 / 2 \mathrm{Lx} \mathrm{I}^{2}$

$E I=1 / 2{\mathrm{C} v E^{2}+1 / 2 \mathrm{~L} \mathrm{I}^{2}}^{2}$ 


\section{2 \\ $\mathrm{v}=$ \\ $\mathrm{CE} / \mathrm{I}+\mathrm{LI} / \mathrm{E}$}

Dari, I $=\mathrm{C} \mathrm{E} \mathrm{v}$

$$
\frac{E}{I}=\frac{I}{C V}
$$

Substitusikan, diperoleh

$$
\begin{aligned}
& \mathrm{v}=\frac{2}{\mathrm{I} / \mathrm{v}+\mathrm{LC} \mathrm{V}} \\
& \mathrm{v}=\frac{\mathrm{I}}{\mathrm{LC}} \text { atau } \\
& v= \pm \sqrt{\frac{1}{L C}} \ldots \ldots \ldots
\end{aligned}
$$

Kedua harga $+\mathrm{v}$ dan $-\mathrm{v}$ berlaku, yaitu

$\mathrm{v}$ positif $=$ gelombang maju

$\mathrm{v}$ negative $=$ gelombang mundur

Untuk kawat hantaran udara jari-jari $\mathrm{r}$ dan tinggi $\mathrm{h}$ diatas tanah, mempunyai harga induktansi dan kapasitas masing-masing:

$$
L=\left(\frac{1}{2}+\frac{2 h}{r}\right) 10^{-9} \text { Henry/cm }
$$

Faktor $1 / 2$ yang ditimbulkan pada induktansi persamaan (3.7), disebabkan oleh adanya fluks didalam kawat (Internal Flux(, dengan pemisahaan distribusi arus merata. Tetapi pada gelombang berjalan, "Transient Skin Effect" sangat besar, sehingga arus berkumpul pada permukaan kawat. Dengan demikian internal fluks lingkup sangat kecil dan dapat diabaikan, menjadi :

$$
\begin{gathered}
\mathrm{L}=2 \operatorname{In} \frac{2 \mathrm{~h}}{2} 10^{-9} \text { Henry } / \mathrm{cm} \\
C=\frac{10^{-11}}{18 \ln \left(\frac{2 h}{r}\right)} \text { Farad } / \mathrm{cm} \ldots \ldots . . .
\end{gathered}
$$

jadi dengan mensubtitusi persamaan (3.8) dan (3.9) kepersamaan (3.6) akan diperoleh kecepatan gelombang berjalan sebesar :

$$
\mathrm{v}=3.10^{10} \mathrm{~cm} / \text { detik }
$$

Dari persamaan (3.10) terlihat bahwa kecepatan gelombang berjalan pada kawat hantaran udara adalah sama dengan kecepatan cahaya dalam hampa udara.Sedangkan untuk kabel 
konduktor padat dengan jari-jari (r) dan isolasi pembungkus berjari-jari (R) serta permitivitas $(\varepsilon)$ :

\begin{tabular}{|c|c|c|c|c|c|}
\hline & $\mathrm{R}$ & 1 & $\mathrm{r}^{2}$ & $\mathrm{r}^{4}$ & $\mathrm{r}^{6}$ \\
\hline (In & $\longrightarrow$ & & & $\overline{12 R^{4}}$ & $\longrightarrow \mathrm{R}^{6} 10^{-9}$ \\
\hline
\end{tabular}

Tetapi fluks lingkup dalam dapat diabaikan, karena $\mathrm{r}$ jauh lebih kecil dari $\mathrm{R}$ maka

$$
\mathrm{r}^{2}
$$

- dan seterusnya dapat diabaikan, maka akan didapat :

$3 \mathrm{R}^{2}$

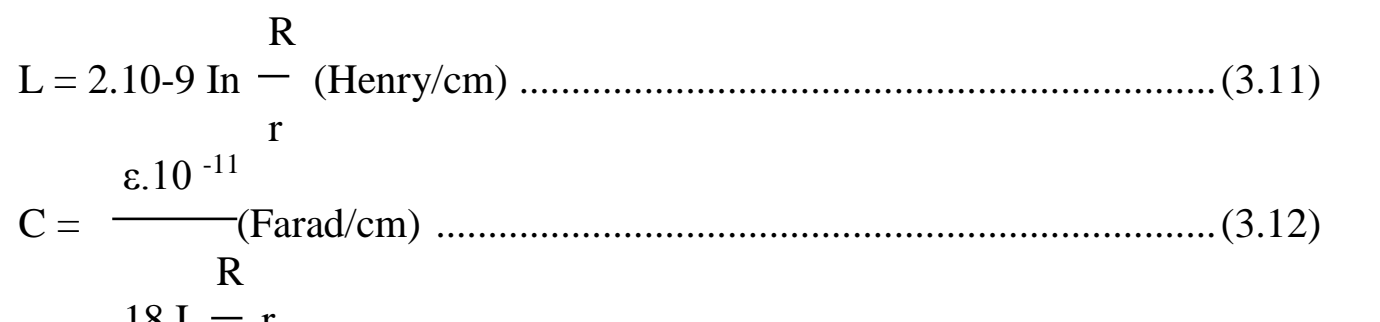

$18 \mathrm{I}-\mathrm{r}$

Jadi kecepatan merambat pada kabel adalah :

$\mathrm{v}=\frac{3.10}{\sqrt{\varepsilon}} \mathrm{cm} / \mathrm{detik}$

Untuk kabel-kabel yang tersedia umumnya $\varepsilon-2.5-4$ jadi kecepatan merambat dalam kabel kira-kira $1 / 2$ sampai ${ }^{2} / 3$ kecepatan cahaya.

\subsection{Bentuk dan Spesifikasi dari Gelombang}

Bentuk umum suatu gelombang berjalan digambar sebagai berikut :

Gambar 3.2 : Spesifikasi gelombang

a. Spesifikasi gelombang berjalan

b. Muka dan ekor gelombang

Spesifikasi dari suatu gelombang berjalan :

a. Tegangan puncak (Crest) dari gelombang, E (KV), yaitu amplitude maksimun dari gelombang.

b. Muka gelombang (Front), $\mathrm{t}_{1}$ (mikrodetik), yaitu waktu dari permulaan sampai puncak. Dalam praktek ini diambil dari $10 \%$ E samapi $90 \% \mathrm{E}$, lhat gambar 3.2b.

c. Ekor gelombang (Tail) yaitu bagian kebelakang puncak. Panjang gelombang (Lengght) $\mathrm{t}_{2}$ (mikrodetik) yaitu waktu dari permulaan sampai titik $50 \%$ E pada tail.

d. Polaritas (Polarity) yaitu polaritas dari gelombang positif atau negative. Suatu gelombang berjalan (surja) dinyatakan sebagai berikut :

$\mathrm{E}, \mathrm{t}_{1} \times \mathrm{t}_{2}$

Jadi suatu gelombang dengan polaritas positif, crest $=1000 \mathrm{KV}$, front 3 mikrodetik, dan panjang 21 mikrodetrik dinyatakan sebagai : + 1000, 3 x 21 .

\subsection{Ekspresi Matematis Gelombang Berjalan}

Ekspresi dasar dari gelombang berjalan secara matematis dinyatakan dengan persamaan dibawah ini : 
$e(t)=E\left(e^{-a} t-e^{-b t}\right)$

$\mathrm{E}$, a dan $\mathrm{b}$ adalah konstanta.

Dari variasi a dan b dapat dibentuk berbagai macam bentuk gelombang yang dapat dipakai sebagai pendekatan dari gelombang berjalan, misalkan :

a. Gelombang persegi yang sangat panjang :
a. $=0$
$\mathrm{b}=\infty$
$\mathrm{e}=\mathrm{E}$

b. Gelombang eksponsial
$\mathrm{a}=\infty$
$\mathrm{e}=\mathrm{E} \mathrm{e}^{-\mathrm{at}}$

c. Gelombang dengan muka linier

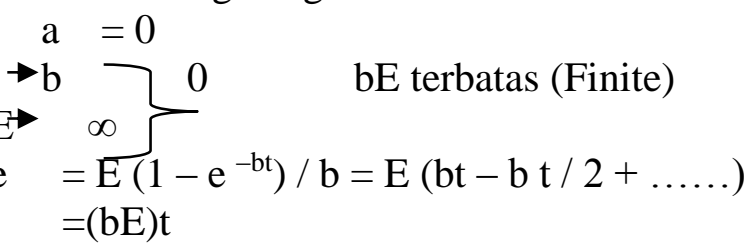

d. Gelombang Snus Teredam
a. $=\alpha-\mathrm{jw}$
b. $=\alpha+\mathrm{jw}$
$\mathrm{E}=\mathrm{E}_{0} / 2 \mathrm{j}$
e. $=E / 2 j e^{-\alpha t}\left(e^{j w t}-e^{-j w t}\right)=E e^{-\alpha t} \sin w t$

e Gelombang kilat tipikal

$\left.\begin{array}{l}\mathrm{a} \\ \mathrm{b}\end{array}\right\}$ Terbatas serta riil

c

Bentuk-bentuk gelombang yang lain dapat dimisalkan sebagai kombinasi dari bentukbentuk diatas.

Gambar. 3.4 Gelombang Kombinasi

Gelombang persegi yang sangat panjang sering digunakan dalam mengitung gelombang berjalan terhadap keamanan sistem, kerena gelombang seperti ini paling berbahaya bagi peralatan. Kecuraman gelombang akan menyebabkan gradient yang maksimun sedangkan ekor yang panjang menyebabkan osilasi maksimun pada belitan kumparan mesin.Gangguan kilat tipikal merupakan bentuk yang paling mirip dengan bentuk gelombang surja petir(Lighting surge) yang dilihat pada osiloskop. Bentuk gelombang ini tergantung dari a dan b, sebaliknya bila spesifikasi gelombang diberi a, b, dan E dapat dicari. Bila E, a, b, diketahui dapat ditentukan puncak, muka, dan panjang gelombang itu.

\subsubsection{Puncak dan Ekor (Crest dan Tail)}

Crest terjadi pada saat $\mathrm{t}=\mathrm{t}_{1}$, yaitu waktu untuk mencapai tegangan puncak

d e $t$

$$
\begin{aligned}
& \underset{d t}{ } E\left(-a e^{-a t}-b e^{-b t}\right)=0 \\
& a e^{-a t 1}=b e^{-b t 1}
\end{aligned}
$$




\section{Maka}

$$
\begin{aligned}
& \mathrm{t} 1=\frac{\operatorname{In~} \mathrm{b} / \mathrm{a}}{\mathrm{b}-\mathrm{a}}=1 / \mathrm{a} \frac{\operatorname{In~} \mathrm{b} / \mathrm{a}}{\mathrm{b} / \mathrm{a}-1}=\mathrm{B} / \mathrm{a} \\
& \text { dan } \\
& \mathrm{E}_{\text {puncak }}=\mathrm{E}\left(\mathrm{e}^{-\mathrm{B}}-\mathrm{e}^{\mathrm{Bb} / \mathrm{a}}\right) \ldots \ldots \ldots \ldots \ldots \ldots \ldots \ldots \ldots \ldots \ldots \ldots \ldots \ldots \ldots \ldots \ldots \ldots \ldots \ldots \ldots
\end{aligned}
$$

\subsubsection{Panjang Gelombang}

Waktu sampai $1 / 2$ puncak $=\mathrm{t}_{2}$

$$
\begin{gathered}
\mathrm{E}_{\text {puncak }} / 2=\mathrm{E}\left(\mathrm{e}^{-\mathrm{Bt} 2 / \mathrm{t} 1}-\mathrm{e}^{-\mathrm{bt}} 2\right) \\
=\mathrm{E}\left(\mathrm{e}^{-\mathrm{Bt}} / 2 \mathrm{t} 1-\mathrm{e}^{(\mathrm{b} / \mathrm{a}) \mathrm{Bt}} 2^{/ \mathrm{t}} 1\right) \\
1 / 2 \mathrm{E}\left(\mathrm{e}^{-\mathrm{B}}-\mathrm{e}^{-\mathrm{Bb} / \mathrm{a}}\right)=\mathrm{E}\left(\mathrm{e}^{\mathrm{Bt} 2 / \mathrm{t} 1}-\mathrm{e}^{-(\mathrm{b} / \mathrm{a}) \mathrm{Bt}} 2_{2} / \mathrm{t} 1\right)
\end{gathered}
$$

Persamaan ini menyatakan hubungan antara $t_{2} / t_{1}$ untuk berbagai tertentu dari b/a. Tetapi karena persamaan ini transcendental, maka untuk mencari $t_{2} / t_{1}$ karena dengan jalan mengisi harga-harga tertentu (membuat grafik) atau dengan jalan pendekatan.Grafik yang dipergunakan dibawah ini :

Gambar. 3.5 Grafik Panjang Gelombang

Grafik ini menunjukan hubungan-hubungan :

at ${ }_{1}$ sebagai b/a dari persamaan (3.11) $E_{\text {erest }} / \mathrm{E}$ sebagai b/a dari persamaan (3.15) $\mathrm{t}_{2} / \mathrm{t}_{1}$ sebagai fungsi b/a dari persamaan (3.16).

Contoh penggunaan grafik untuk menetukan konstanta-konstanta $\mathrm{a}, \mathrm{b}$, dan $\mathrm{E}$, untuk gelombang $+1000,3 \times 21: \mathrm{t}_{2} / \mathrm{t}_{1}=7$. Dari lengkungan $\mathrm{t}_{2} / \mathrm{t}_{1}$ didapat $\mathrm{b} / \mathrm{a}=28.5$, Selanjutnya dari $\mathrm{b} / \mathrm{a}$ ini didapat at $1=0,122 / 3=0,28$

$$
\begin{gathered}
\text { Jadi } \quad: \quad \mathrm{a}=0,122 / \mathrm{t}_{1}=0,122 / 3=0,041 \\
\mathrm{~b}=28,5 \mathrm{a}=28,5 \times 0,041=1,15 \\
\mathrm{E}=\mathrm{E}_{1} / 0,825=1000 / 0,825=1175
\end{gathered}
$$

Gelombang tersebut adalah

$\mathrm{E}=1175\left(\mathrm{e}^{-0,041}-\mathrm{e}^{-1,151}\right)$

\section{HASIL PENELITIAN DAN IMPLEMENTASI}

Seperti kita ketahui bahwa kilat merupakan suatu aspek gangguan yang berbahaya terhadap saluran transmisi yang dapat menggagalkan keandalan dan keamanan system tenaga dan tak mungkin dihindari, sedangkan alat-alat pengaman seperti, arrester, fusegap dan rodgap terbatas kemampuanya, maka untuk mengurangi akibat yang ditimbulkan digunakan kawat sehingga koordinasi isolasi akan ekonomis .Penggunaan kawat tanah di tujukan untuk pengaman saluran transmisi terhadap sambaran kilat. Khususnya sambaran langsung mengenai kawat fasa. Disini kawat tanah berfungsi sebagai perisai. Energi sambaran kilat akan dialirkan ke dalam tanah melalui menara atau tiang yang ditanahkan oleh tanah tersebut.Diantara pertimbanganpertimbangan yang diambil dalam perancangan pemeriaian saluran transmisi adalah letak kawat tanah terhadap kawat fasa. Karena kawat tanah harus diletakkan sedemikian rupa, maka sembaran-sambaran kilat terpusat pada kawat tanah saja sehingga persentase kecil saja pada kawat fasa. 


\subsection{Kawat Tanah UDara (Overhead Ground Wire)}

Kawat tanah udara adalah kawat konduktor, st atau AsCR ditempatka diatas kawat-kawat fasa. Mulanya kawat ini dimaksudkan sebagai proteksi terhadap induced stroke (induksi yang disebabkan oleh sambaran kilat disekitar kawat transmisi, jadi sambaran tidak langsung). Akan tetapi kemudian ternyata dari praktek maupun teori sebagi utama yang menimbulkan gangguan adalah sambaran langsung atau direct stroke.

\subsubsection{Sambaran Tak Langsung (Induced Stroke)}

Ketika arus listrik melalui awan jatuh kebumi, arus listrik tersebut menginduksi ditanah terhadap pengkutuban yang berlawanan dengn awan itu (Gambar.4.1).Bentuk kawasan awan tersebut terhadap menyebar dan menutup sebagian permukaan tanah, permukaan tanah yang tertutup itu lebih besar dari pada permukaan awan itu sendiri. Dasar bagian bawah dari pada awan itu biasanya bersifat negatif, jadi induksi arus listrik di bumi biasanya bersifat positif. Jika kawat transmisi merupakan suatu garis pemisah antara permukaan awan dan tanah, arus listrik akan kelihatan di permukaan garis konduktor dan kawat tanah.

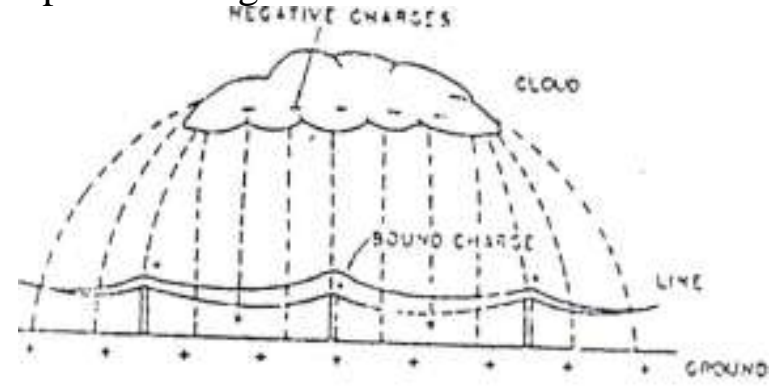

Gambar 4.1. Daerah awan dan batasan dari anah dan jaringan transmisi

Kumpulan arus listrik pada garis konduktor disebabkan oleh kebocoran sekliling isolator dan perputaran dari pada konudktor diluar pengaruh awan. Arus listrik lebih mudah mengumpul diatas kawat tanah dengan perpindahan tegak lurus terhadap menata dari tanah.Jika sambaran yang berasal dari awan mengenai tanah dekat garis pemisah, daerah awan akan runtuh pada waktu tertentu dan lompatan arus listrik digaris konduktor dan bebas bergerak berlawanan arah, membentuyk putaran gelombang mungkin berakhir membentuk dataran aliran arus (Gambar 4.2).

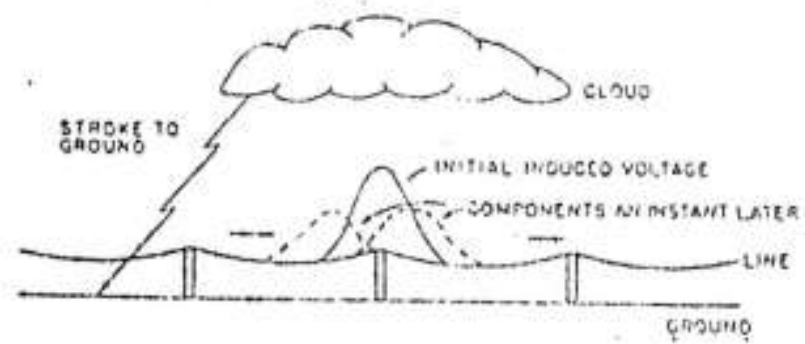

Gambar. 4.2. Induksi tegangan di jaringan transmisi dengan keruntuhan daerah awan. 
Jurnal Qua Teknika, Vol. 6 No. 1 Maret 2016

p ISSN: 2088 2424; e ISSN: 2527 3892

UNISBA Blitar, Http://qua.unisbablitar.ejournal.web.id

Bambang Satria Purwita. 2016. Kontak Pemutus Daya Pada Tegangan Pemulihan Dalam Melindungi Jaringan Transmisi Tegangan Tinggi. Jurnal Qua Teknika, (2016), 6(1):16 31.

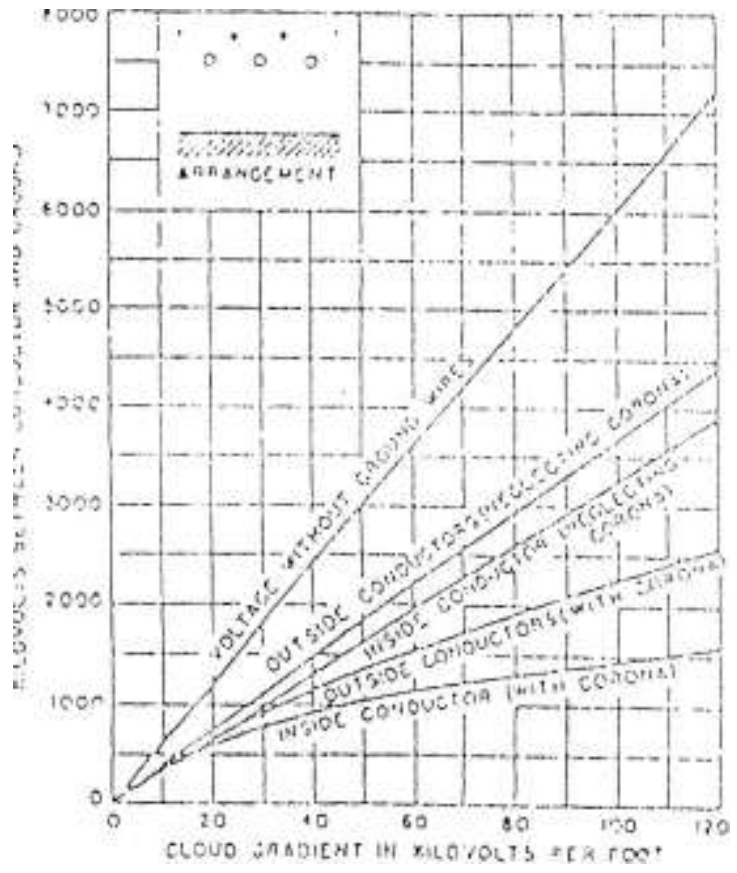

Gambar.4.3. Induksi potensial diantara konduktor dan tanah dekat stroke dari awan ke tanah. Didalam diagram terbuka digambarkan jaringan konduktor., dan lingkaran hitam kawat tanah udara.

Arus listrik pada bawah kawat tanah berbatasan dengan menara-menara dan pada garis konduktor bergerak sangat cepat dan menghilangkan secara brangsur-angsur di corona serta kehilangan muatan. Tegangan listrik muncul digaris abtas tergantung kepada perbandingan (ukuran) dari pada keruntuhan daerah awan dan kapasitas kemampuan ruangan antara jaringan dan tanah, kalau circuit tanpa kawat-kawat tanah udara, dan kalau terjadi keruntuhan daerah awan pada waktu nol, tegangan listrik di konduktor akan sebanding dengan peningkatan potensial gradien dari pengadaan pembesaran ketinggian awan dari pada kawat tanah udara diatas permukaan tanah menambah kekautan penghantar dibumi, dan dengan peningkatan awan yang banyak mendatangkan lingkaran cahaya, kapasitas selanjutnya bertambah sebab efektif diameter tanah bertambah dengan lingkaran cahaya.

Gambar 4.3. menunjukkan induksi tegangan listrik antara penghantar dan tanah untuk perbedaan gradien awan dan tanpa kawat tanah, untuk jaringan diatas ketinggian tanah dan jarak antara konduktor dari pada rata-rata jaringan tegangan tinggi.Perbandingan perhitunganperhitungan tegangan dari konduktor dengan proteksi kawat tanah dengan perbandingan tegangan yang ada pada konduktor tanpa proteksi kawat tanah.Gambar 4.3. Menunjukkan perbandingan pengaman kira-kira 0,25 untuk bagian dalam konduktor, apabila dalam perbandingan perhitungan lingkaran cahaya. 


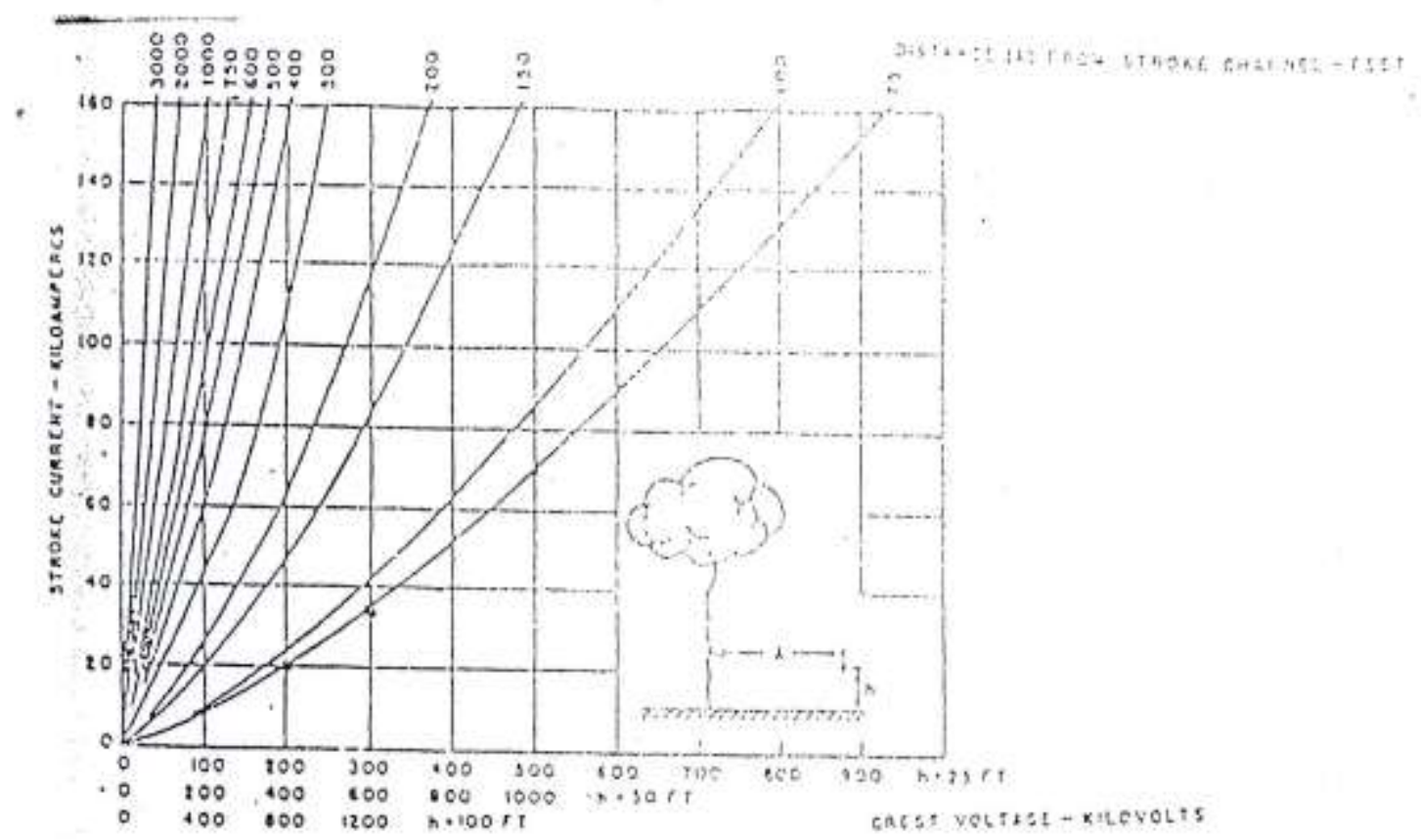

Gambar 4.4. Menghitung harga dari puncak tegangan induksi pada jaringan transmisi dekat stroke, menggambarkan dari arus stroke, jarak saluran dari arus stroke, jarak saluran darai ketinggian konduktor

Tegangan menghasilkan keseimbangan ketinggian dari konduktor jaringan transmisi puncak dari arus listrik kepada sambaran ke tanah dan ajrak dari saluran sambaran.Gambar 4.4. memberikan perhitungan tertinggi dari pada penginduksian arus listrrik yang bergelombang pada sebuah konduktor yang tidak dilindungi oleh kawat tanah udara dan berfungsi sebagai sambaran arus, jarak dari aliran samabran dan ketinggian dari pada penghantar. Perhitungan pada kurva seperti terlihat pada Gambar 4.4. dapat diketahui kecepatan arus listrik bolak-balik untuk perbedaan arus listrik pada suatu tempat sebagai berikut : 0-50.000 ampere 120 kaki per us; 50.000-10.000 amperes, 400 kaki per us.Gambar 4.4. memperlihatkan keadaan yang kurang baik dari pada gambar arus yang tinggi, susunan transmisi yang tinggi dan sambaran kepermukaan tanah dekat susunan transmisi, puncak tegangan yang pertama pada ukuran $1000 \mathrm{KV}$ mungkin dapat menginduksi dibawah konduktor. Pengurangan isi dapat terlihat jika kawat-kawat tanah udara yang melalui udara dapat dikurangi.

\subsubsection{Sambaran Langsung Pada Menara}

Untuk sambaran langsung, kawat tanah melindungi (shileding) kawat fasa, dan untuk memperoleh perlindungan yang baik kedudukan kawat tanah harus memenuhi beberapa persyaratan yang penting.

a. Kawat tanah harus cukup tinggi diatas kawat fasa dan diatur sedemikian rupa agar dapat mencegah sambaran pada kawat-kawat fasa.

b. Pada tengah gawang kawat tanah harus mempunyai jarak yang cukup di atas kawat fasa untuk mencegah terjadinya loncatan sebagian pada waktu yang diperlukan untuk 
gelombang pantulan negatif dari menara kembali ke tengah gawang dan ini akan mengurangi tegangan pada tengah gawan.

c. Tahanan kaki menara harus cukup rendah untuk membatasi tegangan pada isolator agar tidak terjadi loncatan api pada isolator.

d. Bila dipakai untuk proteksi terhadap gardu induk, kawat tanah harus cukup panang sehingga surja yang masuk dapat diredam sampai harga yang tidak berbahaya sewaktu mencapai gardu induk

Sambaran langsung merupakan sebab utama dari gangguan yang disebabkan oleh kilat.Bila sambaran mengenai menara transmisi, arus yang besar sekali mengalir ke tanah dan sepasang gelombang berjalan merambat pada kawat tanah.Untuk memudahkan perhitungan, untuk sementara impedansi surja menara dapat diabaikan dan diasumsikan menara dibumikan melalui tahanan yang konstan R.Gambar 4.5. menunjukkan sambaran kilat dengan impedansi surja $\mathrm{z}$ ke menara, pada keadaan ideal.Bila diperhatikan persamaa-persamaan diatas, terlihat bahwa hasil yang sama akan diperoleh bila kilat tersebut mempunyai surja Z, menara pertama dibumikan melalui tahanan $\mathrm{R}$, dan kawat fasa serta kawat tanah hanya menuju satu jurusan dari menara 1 (Gambar 4.9).

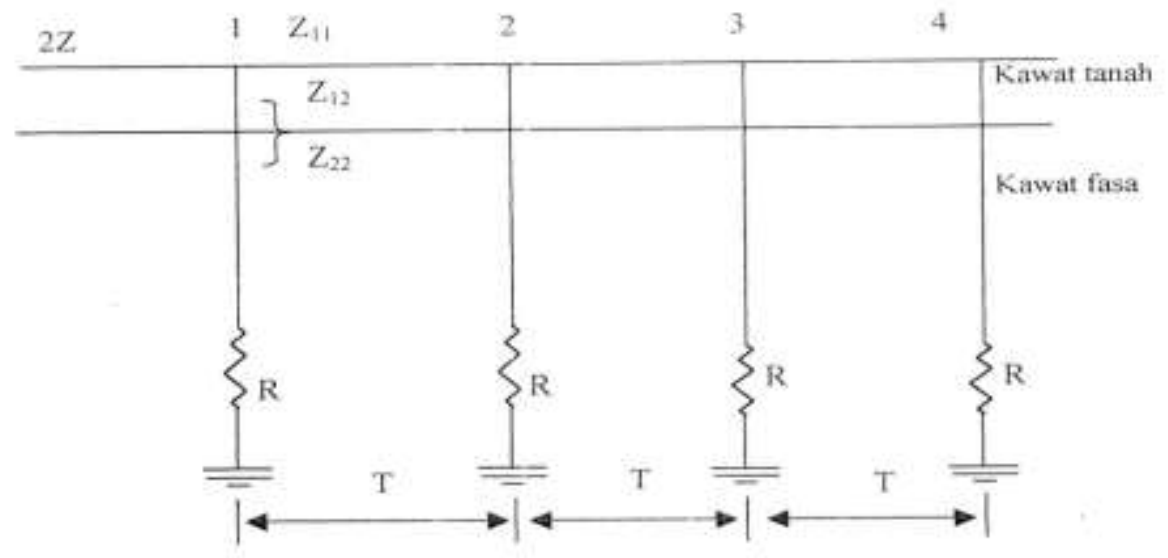

Gambar. 4.9. Rangkaian Ekivalen circuit dari gambar 4.5

\subsubsection{Efek Tahanan Kaki Menara}

Tahanan kaki menara yang rendah mempunyai lima kebaikan :

1. Mengurangi tegangan kawat tanah

2. Mengurangi tegangan kawat fasa

3. Mengurangi tegangan apa isolator

4. Membatasi gangguan pada jarak yang kecil

5. Memperpendek lama terjadinya tegangan yang berbahaya

Gangguan yang menyebabkan sambaran langsung yang mempengaruhi kawat bukanlah sautu gelombang sederhana yang dirambatkan sepanjang transmisi, melainkan gelombang yang timbul oleh pantulan berulang, dan ini harus dibatasi pada jarak yang pendek serta harus cepat dibatasi.

\subsubsection{Efek Bentuk Gelombang}


Makin panjang front gelombang serta makin rendah tegangan akan menyebabkan gelombang pantulan yang timbul dan telah mulai memperkecil gelombang datang.

\subsubsection{Sambaran pada Pertengahan Dua Menara (Midspan)}

Tegangan-tegangan tersebut tetap ada sampai reduksi oleh gelombang-gelombang refleksi dari menara-menara.Bila panjang span dalam mikro detik adalah $\mathrm{T}$, maka waktu tersebut harus melampaui sebelum reduksi terjadi. Selama itu, flashover antara kawat tanah dan kawat fasa harus cukup jauh sehingga sparkover voltage (tegangan tembus) tidak tercapai sebelum gelombang releksi tiba yang akan mereduksi tegangan midspan itu.

\subsubsection{Perlindungan Gardu Induk}

Perlindungan gardu induk terbagi dalam 2 bagian :

a.Perlindungan terhadap sambaran langsung

b.Perlindungan terhadap gelombang yang datang dari kawat transmisi

Perlindungan terhadap sambaran langsung ialah dengan kawat tanah. Bila perlindungan ini sempurna, maka yang perlu diperhatikan adalah gelombang yang datang dari kawat transmisi.Bila kawat-kawat fasa cukup terlindung dari sambaran langsung, maka sumber gelombang berjalan biasanya adalah lompatan api dari isolator, umumnya tegangan ini lebih tinggi dari tingkat isolari dasar (ITD) dari peralatan gardu, tegangan lebih iniharus dilakukan ke tanya oleh arrester atau alat-alat perlindungan lainnya.

Untuk menghitung tegangan impuls pada gardu, didefenisikan dengan dua hal:

a.Daerah bahaya atau vulnarable zone, ialah jarak diluar kawat dimaan suatu gelombang surja dapat timbul dan membahayakan gardu.

b.Indeks terusan gardu atau "station refraction index" ialah ukuran dari perubahan puncak dan muka gelombang yang dialaminya ketika memasuki gardu.

Panjang dari bahaya merupakan fungsi dari :

a.Redaman dan distorsi gelombang pada saluran

b.Indeks terusan dari gardu induk

Sedang indeks terusan itu sendiri tergantung pada :

a. Bentuk gelombang datang

b. Karakteristik peralihan dari peralatan gardu dan alat-alat perlindungan.

Sepanjang perambatan pada kawat transmisi, gelombang mengalami redaman dan distorsi yang disebabkan oleh korona, pengaruh kulit, resitivitas tanah, dan gendengan. Selain itu, bentuknya juga dapat berubah karena pantulan ketika mencapai gardu.

\subsection{Akibat Pelindung Kawat Tanah}

Sebagai akibat dari mengalirnya energi sambaran ke dalam tanah, maka tegangan lebih yang timbul pada isolator saluran akan dapat dibatasi, dengan demikian penembusan pada isolator dapat dibatasi. Untuk memperoleh hasil yang unik maka penempatan kawat tanah haruslah memenuhi syart, antara lain :

1. Kawat tanah harus cukup tinggi di atas fasa dan diatur sedemikian rupa agar dapat mencegah sambaran langsung pada kawat-kawat fasa. 
2. Pada tengah gawang kawat tanah harus mempunyai kawat fasa untuk mencegah terjadinya loncatan sebagian

3. Tahanan kaki menara harus cukup rendah.

\subsection{Kegagalan Pelindung}

Mulai tahun 1920-an telah banyak teori-teori, percobaan-percobaan dan pengalamanpengalaman dikemukakan para penyelidik mengenai fungsi kawat tanah untuk melindungi kawat fasa pada saluran transmisi.Pada tahun 1960 Provoost mengemukakan suatu resume yang sangat baik mengenai peranan kawat tanah. Berdasarkan teori itu Provoost menarik kesimpulan bahwa :

1. Untuik sudut pelindung $\theta \leq 18^{0}$ perisaian kawat transmisi itu baik

2. Untuk sudut pelindung $18^{0} \leq \theta<30^{\circ}$ kurang baik

3. Untuk sudut pelindung $\theta 30^{\circ}$ jelek

Kemudian konstenko, Poloroy dan Rosenfeld dalam tahun 1961 mengemukakan karangan yang lebih menari lagi. Mereka menunjukkan bahwa jumlah gangguan kilat karena kegagalan pelindung adalah sebagai fungsi dari sudut perisaian $\theta$ dan tinggi menara $h_{t}$ seperti terlihat dari relasi empiris persamaan $(4.41)$

$$
\log \varphi=\frac{\theta \sqrt{h_{1}}}{90}-4
$$

\section{Dimana :}

$\varphi=$ Hasil bagi dari jumlah kilat yang menenai kawat fasa dan jumlah kilat yang mengenai saluran transmisi.

$\theta=$ Sudut pelindung pada menara, derajat

$\mathrm{h}_{\mathrm{t}} \quad$ = tinggi kawat tanah pada menara, meter

Jadi jumlah gangguan karena kegagalan pelindung,

$\mathrm{N}_{\mathrm{SF}}=\varphi \mathrm{N}_{\mathrm{L}} \eta$

Pada waktu itu persamaan (4.42) dianggap oleh sebagian besar insinyur saluran transmisi lebih unggul dari cara-cara yang lain.

\subsection{Perhitungan untuk Menentukan Sudut Perlindungan Pada Jaringan Transmisi Tegangan Tinggi}

Besarnya sudut perlindungan mempunyai hubungan-hubungan dengan tinggi menara, dimana semakin tinggi menara transmisi semakin tinggi kemungkinan kegagalan perlindungan.

Untuk melindungi (mengurangi) kegagalan perlindungan ini, haruslah dipilih sudut perlindungan yang kecil. Rumus yang dapat dipakai dalam menghitung sudut perlindungan seperti persamaan :

$$
\theta=\arctan \frac{x}{h}
$$

Dimana $: \mathrm{h}=$ jarak antara kawat tanah dengan garis horizontal yang menghubungkan kawat fasa.

$\mathrm{x}=$ selisih antara panjang cross arm kawat tanah dengan kawat fasa

$\theta=$ sudut perlindungan 
Jurnal Qua Teknika, Vol. 6 No. 1 Maret 2016

p ISSN: 2088 2424; e ISSN: 2527 3892

UNISBA Blitar, Http://qua.unisbablitar.ejournal.web.id

Bambang Satria Purwita. 2016. Kontak Pemutus Daya Pada Tegangan Pemulihan Dalam Melindungi Jaringan Transmisi Tegangan Tinggi. Jurnal Qua Teknika, (2016), 6(1):16 31.

a. Perhitungan sudut pelindung antara kawat tanah dengan kawat fasa $\mathrm{R}$

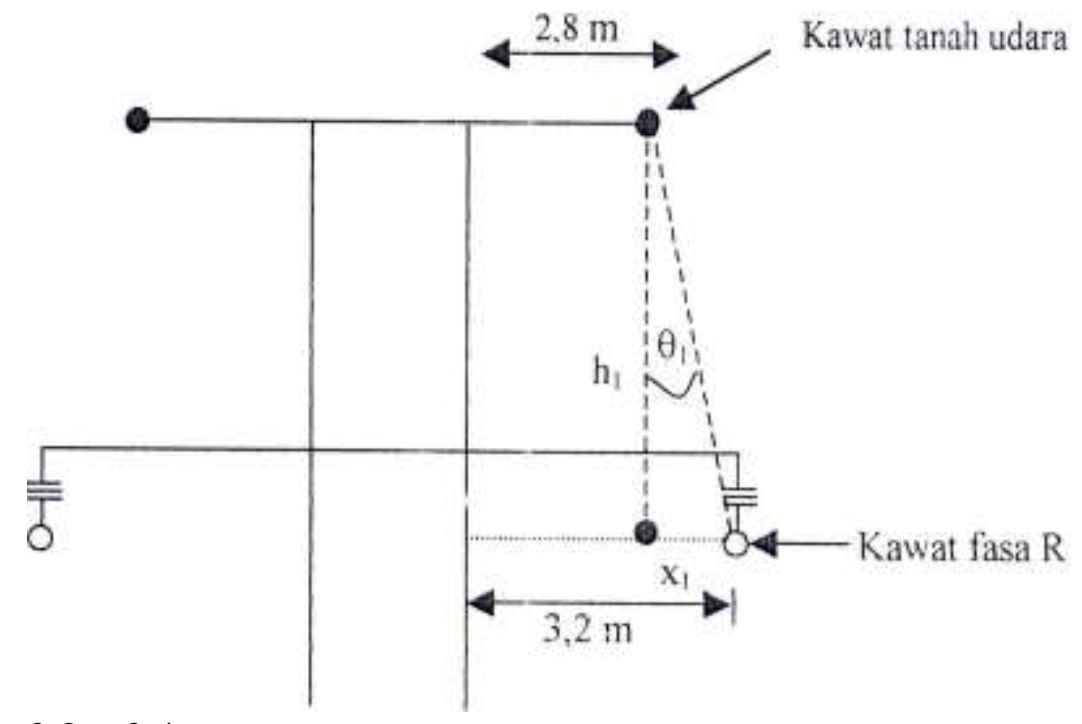

$\mathrm{x}_{1}=3,2-2,8=0,4 \mathrm{~m}$

$\mathrm{h}_{1}=5,22 \mathrm{~m}$

$\theta_{1}=\arctan \frac{x}{h}$

$\theta_{1}=\arctan \frac{0,4}{5,22}$

$\theta_{1}=4,38^{0}$

b. Perhitungan sudut pelindung antara kawat tanah dengan kawat fasa $S$

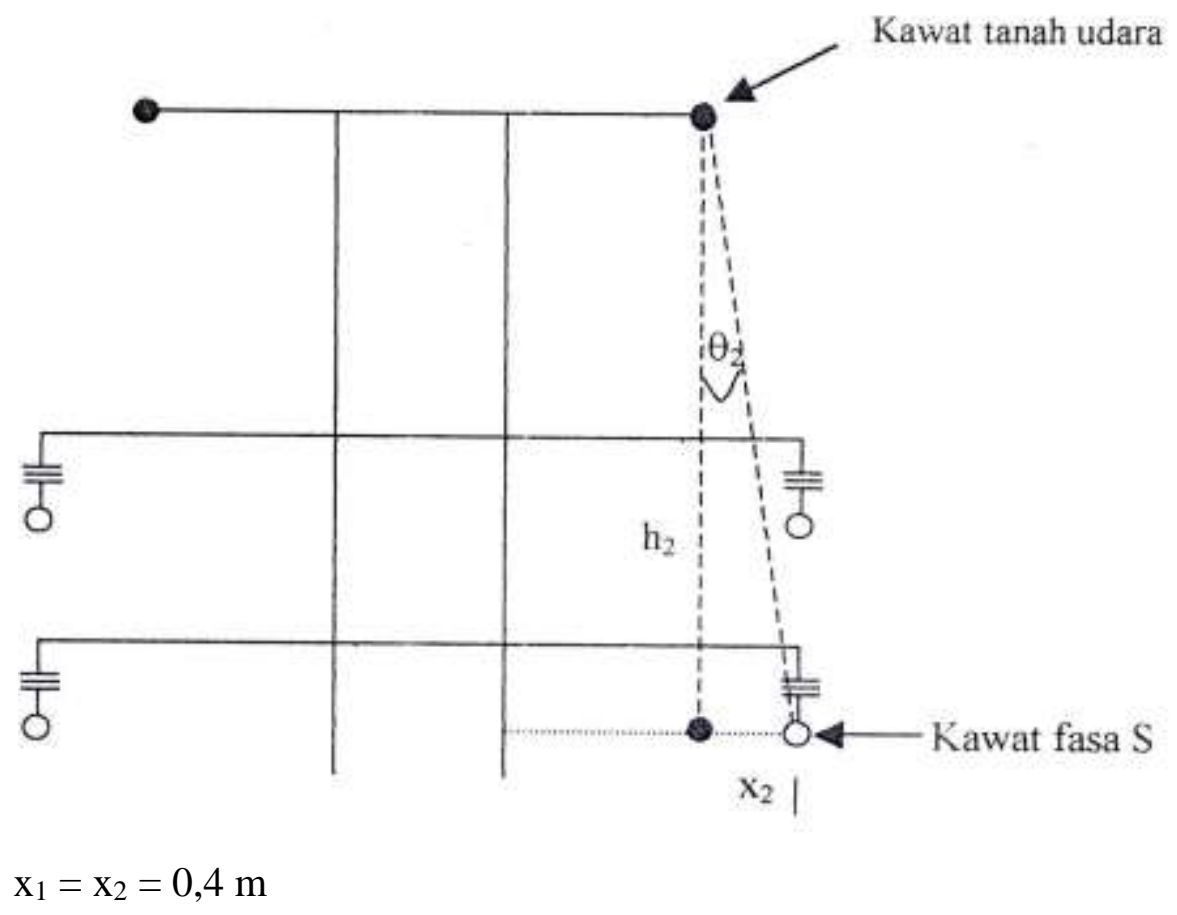




$$
\begin{aligned}
& \mathrm{h}_{2}=5,22+4,38=9,6 \mathrm{~m} \\
& \theta_{2}=\arctan \frac{x_{2}}{h_{2}} \\
& \theta_{2}=\arctan \frac{0,4}{9,6} \\
& \theta_{2}=2,39^{0}
\end{aligned}
$$

\section{c. Perhitungan sudut pelindung antara kawat tanah dengan kawat fasa T}

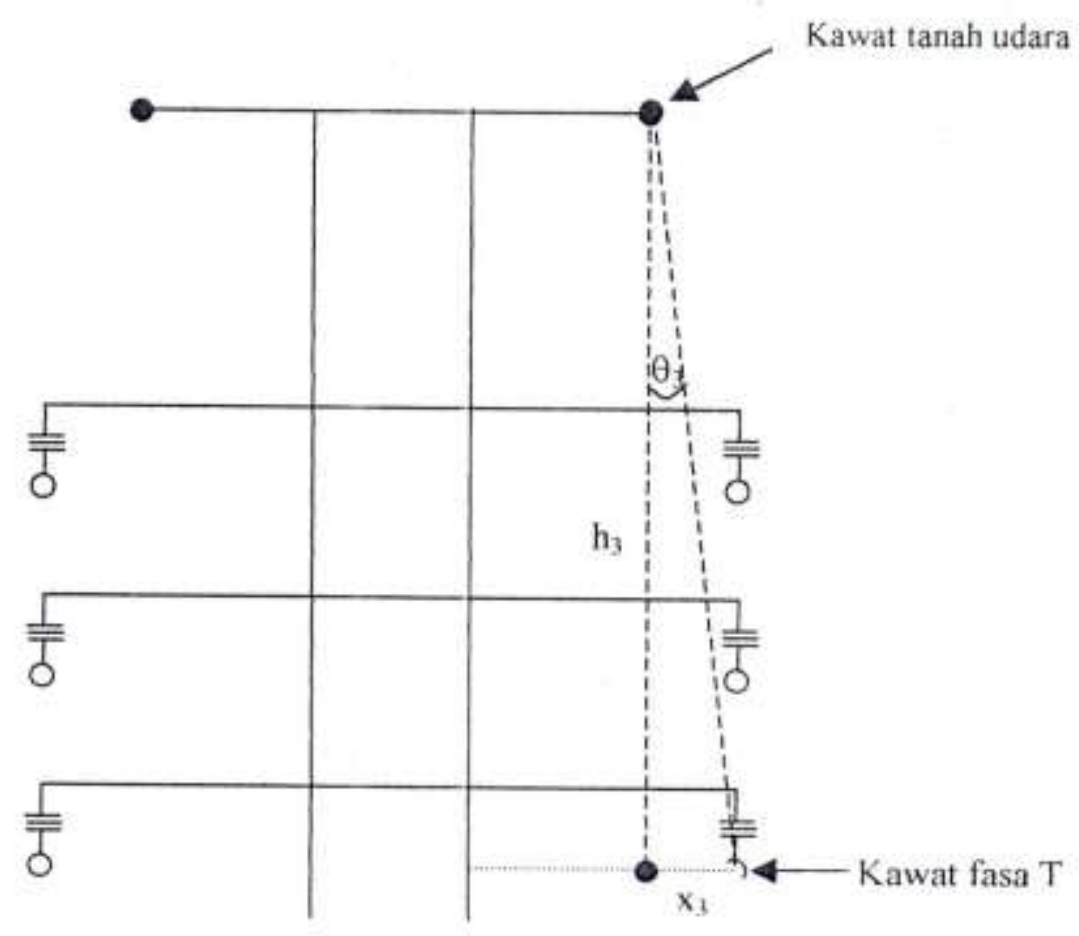

$$
\begin{aligned}
& \mathrm{x}_{1}=\mathrm{x}_{2}=\mathrm{x}_{3}=0,4 \mathrm{~m} \\
& \mathrm{~h}_{3}=5,22+4,38=13,98 \mathrm{~m} \\
& \theta_{3}=\arctan \frac{x_{3}}{h_{3}} \\
& \theta_{3}=\arctan \frac{0,4}{13,98} \\
& \theta_{3}=1,63^{\circ}
\end{aligned}
$$




\section{KESIMPULAN DAN SARAN}

Dari pembahasan pada bab-bab sebelumnya maka penulis mengambil beberapa kesimpulan antara lain :

1. Seringnya gangguan terhadap jaringan transmisi adalah gangguan alam, seperti seringnya gangguan petir terhadap jaringan transmisi yang disebabkan bangunan jaringan transmisi panjang dan terbesar diberbagai daerah serta dalam segala macam kondisi udara.

2. Pada pembangunan jaringan transmisi yang sangat perlu diperhatikan adalah perancangan proteksi saluran transmisi terhadap letak kawat fasa

3. Konfigurasi kawat transmisi ini harus mendapat perhatian yang lebih besar dan serius.

4. Sudut pelindung kawat tanah sesuai dengan contoh perhitungan diperoleh untuk :

a. Nilai dari sudut pelindung antara kawat tanah dengan kawat fasa $R$ adalah $\theta_{1}=4,38^{0}$

b. Nilai dari sudut pelindung antara kawat tanah dengan kawat fasa $S$ adalah $\theta_{2}=2,39^{0}$

c. Nilai dari sudut pelindung antara kawat tanah dengan kawat fasa $\mathrm{T}$ adalah $\theta_{3}=1,63^{0}$

Jadi untu sudut pelindung $\theta<18^{0}$ pelindung kawat transmisi itu baik

5. Kawat tanah udara berfungsi sebagai pengaman guna mengurangi akibat dari sambaran petir secara tidaklangsung.

6. Menara jaringan transmisi dapat menjadi pembumian dengan mengalirkan arus lebih pada kawat tanah melalui menara transmisi.

\section{DAFTAR PUSTAKA}

Abdul M. Mousa, 1976, Shielding of High Voltage And Extra High Voltage Substation, IEEE Transaction on Power Apparatus and System; Vol. PAS-95.

A. Aris Munandar DR., 1978, Teknik Tegangan Tinggi, PT. Pradaya Paramita, Jakarta.

A. Aris Munandar DR., S. Kuwahara DR., 1975, Teknik Tenaga Listrik, Jilid II Saluran Transmisi, PT. Pradaya Paramita, Jakarta.

Hutauruk T. S., 1976. Pengetanahan Netral Sistem-sistem Tegangan Tinggi, Departemen Elektro Teknik Fakultas Teknologi Industri, ITB.

Hutauruk T. S., 1987. Pengetanahan Netral Sistem Tenaga dan Pengetanahan Peralatan, Institut Teknologi Bandung dan Univeristas Tri Sakti.

Hutauruk T. S., 1985. Transmisi Daya Elektrik, Institut Teknologi Bandung dan Univeristas Tri Sakti.

Hutauruk T. S., 1976. Gelombang Berjalan Pada Sistem Transmisi dan Proteksi dan Perlatan Pada Surja, Institut Teknologi Bandung. 